IKONOMIKA: Journal of Islamic Economics and Business

Volume 3, No I (2018)

ISSN : 2527-3434 (PRINT) - ISSN: 2527-5I43 (ONLINE)

Page : $43-52$

\title{
The Role Of Shareholders and Good Corporate Governance In Sharia Banks
}

\author{
Zulpahmi ${ }^{1}$, Sumardi ${ }^{2}$, Muhammad Akmal ${ }^{3}$ \\ Muhammadiyah University of Prof. DR. HAMKA ${ }^{\mathrm{I}, 2,3}$ \\ zulpahmi@uhamka.ac.id ${ }^{1}$,sumardi@uhamka.ac.id², \\ akmal@uhamka.ac.id ${ }^{3}$
}

\begin{abstract}
The variables used in this research are the role of audit committee and internal audit as the dependent variables and the implementation of good corporate governance as the independent variable. This research employs a purposive sampling to determine the samples based on certain criteria and 3 (three) Sharia banks are obtained since they have met the pre-determined criteria. The primary data are obtained through questionnaires distributed to 43 employees of Audit Committee, Internal Auditor, and GCG as the respondents. This research employs a Multiple Linear Regression Analysis as its technical analysis. The results of this research show that the role of audit committee positively and significantly influences the implementation of good corporate governance.
\end{abstract}

Keywords: Audit Committee, internal audit, implementation of Good Corporate Governance

\section{A. INTRODUCTION}

Regarding to Islamic financial services, every institution that offers Islamic financial services is expected to operate pursuant to sharia code of conduct and should serve within sharia limitations. As an effort to ensure that the operation of Islamic financial institution is not contradictory to sharia principles, several institutions serve as advisor and supervisor for such activities. The concept of supervision on financial practices conducted by sharia financial institutions has a number of foundations, which are sharia foundation and positive legal foundation applicable in Indonesia. The sharia foundation is an understanding of QS. Al-Ashr [I03] verse I-3 of which translation is: "By time, Indeed, mankind is in loss, Except for those who have believed and done righteous deeds and advised each other to truth and advised each other to patience." 
A wide understanding and interpretation of these verses show that mankind will generally suffer loss, except they advise each other and control each other. Sharia bank, like conventional bank, serves as financial intermediary, with main duty to collect fund from the community and redistribute it to the community as financing facilities. The underlying difference between both banks is only that sharia bank performs its business activities not based on interest fee, but based on sharia principles or profit and loss sharing principle.

\section{B. THEORITICAL}

Differently with credit definition which requires debtor to return loan by giving interest to the bank, in sharia principles based financing, borrowing shall be returned on a profit and loss sharing under an agreement between the bank and debtor (Adiwarman A. Karim, 2010).

According to the data of the Financial Services Authority (OJK) in 20I7, sharia bank institutionally starts from 3 Sharia Commercial Banks (BUS) and I9 Sharia Business Units (UUS) in 2005 to 13 Sharia Commercial Banks (BUS) and 2I Sharia Business Units (UUS) in March 2017, and from office network perspective, there are 1787 offices in 20I4 and there are 25I8 office in 2017. From such data, change to business environment in globalization era requires development of a new system or paradigm in business and industry management. One of the methods to improve a company's value is with Good Corporate Governance (GCG). This is to view good corporate governance as an assessment system and best practices, which are very fundamental in company operation.

According to Wibowo (2009), in other financial institution's businesses, the higher business transaction volume, the higher possible misuse of trust is, mainly on the part of guarantor. Therefore, Sharia Banking as a financial institution based on Islamic principles should become uswah hasanah in the application of Good Corporate Governance. Banks should be on the front line in the implementation of GCG. The application of Good Corporate Governance in sharia bank does not only improve public trust to sharia bank, but is also part of effort to improve public trust to national banking.

Good Corporate Governance regulation and implementation require commitment of top management and all lines of the organization. The implementation begins with stipulation of strategic policy and code of ethics that should be complied with by all parties in the company. For Indonesian banking, compliance with code of ethics as realized in one word and act constitutes an important factor as the ground for Good Corporate Governance application. 
According to the consideration above and high complexity and risks of banking business, the National Committee for Governance Policy considers it necessary to issue a Guideline to Good Corporate Governance for Indonesia Banking (Indonesian Banking Sector Code) as a complement and an integral part of general guideline to Good Corporate Governance. Banking in this guideline includes Public Bank and People's Credit Bank (BPR) run conventionally or according to sharia principles (Moh Wahyudin;2008).

One of the tools to apply Good Corporate Governance is to make an effective audit committee and internal audit available. In general, an Audit Committee's duty is to help Board of Commissioners perform supervisory function on company's performance, mainly related to review system, company's internal control, ensuring financial statement quality and improving audit function effectiveness. Presence of an independent audit committee in a company may give benefit in effective monitoring.

Therefore, financial statement will be more transparent, stock trade will be more active, and financial statement information will be more accountability as an input to make a contract between stakeholders, senior chairmen, and management. This is in line with the outcome of research by Megasari (2010). This research indicates that the role of Audit Committee significantly influences Good Corporate Governance. This indicates that the hypothesis in such research is accepted. A similar research is conducted by Dian (2012) on PT. Wijaya Karya Tbk which results in similar outcome, that Audit Committee as an realization of Good Corporate Governance has in general been well implemented.

An internal auditor has very important role in everything related to company management and risks related to business operation (Wahyu, 2010: 6). This is in line with the research outcome by Putri (20I4) that an application of internal audit significantly influences Good Corporate Governance, which is supported by the research outcome by Rifda (2016) that an internal audit significantly influences Good Corporate Governance.

Many cases involve audit committee and internal audit in corporate governance and supervisory pattern or more commonly known as Corporate Governance. Internal audit's poor supervision often causes less application of good corporate governance. This may cause company issue poor information to shareholders and the public. Such issues, in combination with economic crisis in Indonesia may cause such company does not long sustain, therefore, the role of audit committee and internal audit is urgently necessary. 


\section{METHODOLOGY}

This is an associative-causal research. According to Sugiyono (2012), associative-causal research is a research intended to disclose causality relationship between 2 (two) or more variables. In this research, the independent variable is the application of audit committee and internal audit, while the dependent variable is Good Corporate Governance.

The population in this research is I3 Sharia Commercial Banks in Indonesia. Each of the banks is assumed to contribute about $\mathrm{I} 6$ respondents.

\section{RESULT AND DISCUSSION}

With an initial assumption that there are \pm 48 respondents in this research, each of the sample banks contributes \pm I6 respondents. From 48 distributed questionnaires, only 45 questionnaires are returned and 3 (three) questionnaires are unreturned, and only 43 can be processed since 2 (two) questionnaires are incomplete. These questionnaires are obtained from 3 (three) sample Sharia Commercial Banks (BUSs), which are Bank Muamalat Indonesia (BMI), Bank Syariah Mandiri (BSM) and Bank BRI Syariah (BRIS).

\section{Result}

The contribution of each bank and the characteristics of each respondent can be found in the following table:

Table I

Bank Name

\begin{tabular}{|ll|l|l|l|}
\hline & & Frequency & Percent & Cumulative Percent \\
\hline Valid & BSM & I2 & 27.9 & 27.9 \\
& BRIS & I5 & 34.9 & 62.8 \\
& BMI & I6 & 37.2 & 100.0 \\
Total & 43 & 100.0 & \\
\hline
\end{tabular}

Source: SPSS Output

In table I, the contribution of BSM in this research is $27.9 \%$ or I2 questionnaires are filled in and can be processed, while BRIS's contribution is $34.9 \%$ with I5 questionnaires may be processed, and BMI's contribution is $37.2 \%$ or $\mathrm{I} 6$ questionnaires may be processed. 
Table 2

Descriptive Statistics

\begin{tabular}{|c|c|c|c|}
\hline & Mean & Std. Deviation & $N$ \\
\hline Implementation of & & & \\
\hline $\begin{array}{l}\text { Good Corporate } \\
\text { Governance }\end{array}$ & 45.3256 & 3.24933 & 43 \\
\hline $\begin{array}{l}\text { Role of Audit } \\
\text { Committee }\end{array}$ & 24.4186 & I.85463 & 43 \\
\hline Role of Internal Audit & $32.8 \mathrm{I} 40$ & 2.37302 & 43 \\
\hline
\end{tabular}

Source: SPSS Output

In table 2 above, we can find that there are 43 questionnaires in this research, as indicated with $\mathrm{N}$ value. The average value of implementation of good corporate governance variable is indicated with a mean value of 45.3256 , while the deviation standard of such variable is 3.24933 . The audit committee variable has a mean value of 24.4I86 with deviation standard of I.85463, while the role of internal audit variable has a mean of 32.8140 with deviation standard of 2.37302 .

\section{Hypothesis Test}

This test shows to what extent an explanatory or independent variable individually can explain dependent variable variation and is used to find out whether there is or there is no influence of each tested independent variable at significance level of 0.05 (Imam Ghozali, 20II). To find out whether there is or there is no influence of each independent variable on the dependent variable, we can compare the probability value ( $p$-value) of each variable with significance level of 0.05 , if the $p$-value is lower than 0.05 , we can say that the independent variables partially and significantly affect the dependent variable.

Another method to make a decision on the hypothesis is to compare the statistical value of $t$ test on the critical value based on $t$ distribution table. To determine the table in this research, view the $t$ distribution table provided that the significance level $\alpha=0.05$, degree of freedom $\mathrm{df}=43-3$, the value of table $=2.02 \mathrm{I}$ is obtained. SPSS:

The table 3 below presents the results of partial regression test ( $t$ test) using 
Table 3

Individual Significance Test on Partial Regression Coefficient Coefficients $^{2}$

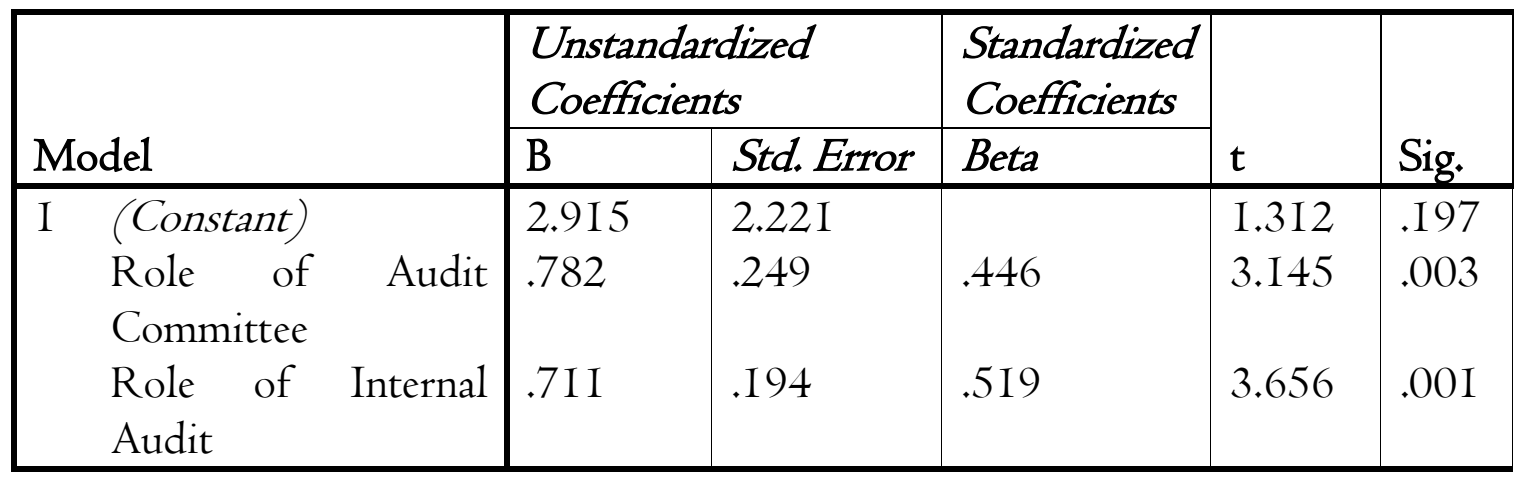

Dependent Variable: Implementation of Good Corporate Governance Source: SPSS Output

According to table 3 , the influence of independent variable on dependent variable can be explained as follows: Table 23 shows that the significant probability value of the role of audit committee variable is $0.003<0.05$, with the value tcount $3.145>$ table $2.02 \mathrm{I}$, thus we may conclude that $\mathrm{H}_{\mathrm{I}}$ is accepted, which means that the hypothesis test results show that the role of audit committee variable partially influences the implementation of good corporate governance variable.

According to table I, the application of internal audit has significant probability value of $0.00 \mathrm{I}<0.05$, with value $\mathrm{t}_{\text {count }} 3.656>\mathrm{t}_{\text {table }} 2.02 \mathrm{I}$, thus we may conclude that $\mathrm{H}_{2}$ is accepted, which means that the hypothesis test results show that the role of internal audit variable partially influences the implementation of good corporate governance variable.

F statistic test is used to find out the influence of all independent variables mutually included into the regression model on the dependent variable tested at significance level of 0.05 (Imam Ghozali, 20II). In other words, this tests whether the role of audit committee and internal audit variables mutually or simultaneously influences the implementation of good corporate governance variable. This is to compare the probability value ( $p$-value) with the significance level of 0.05 , if the $p$ value is lower than 0.05 , we can say that the independent variables simultaneously and significantly affect the dependent variable, or by comparing $\mathrm{F}_{\text {count }}$ with $\mathrm{F}_{\text {table }}$ at significance rate of $\alpha=5 \%$ with dfI $=3-\mathrm{I}$ and $\mathrm{df} 2=43-3$, the value $\mathrm{F}_{\text {table }}=3.23$ is obtained. The results of simultaneous significance test (F test) using SPSS 22 is presented in table 4 below: 
Table 4

Simultaneous Significance Test (F Test)

ANOVA $^{a}$

\begin{tabular}{|ll|l|l|l|l|l|}
\hline Model & Sum of Squares & df & $\begin{array}{l}\text { Mean } \\
\text { Square }\end{array}$ & $\mathrm{F}$ & Sig. \\
\hline I $\quad \begin{array}{l}\text { Regression } \\
\text { r Residual }\end{array}$ & 400.378 & 2 & 200.189 & I85.946 & .000 \\
& Total & 44.064 & 40 & 1.077 & & \\
\hline
\end{tabular}

Predictors: (Constant), Role of Internal Audit, Role of Audit Committee

Dependent Variable: Implementation of Good Corporate Governa

Source: Output SPSS 22, 2017

Table 4 above shows that the significance probability value of independent variables is $0.000<0.05$, with value $F_{\text {count }}$ of $185.946>F_{\text {table }}$ of 3.23 , thus we may conclude that $\mathrm{H}_{3}$ is accepted, which means that the hypothesis test results show that the role of audit committee and internal audit variables simultaneously influences the implementation of good corporate governance variable.

Determination coefficient $\left(R^{2}\right)$ is a value (proportional value) to measure to what extent free variables used in regression equation are able to explain non-free variable variation. The determination coefficient value ranges from 0 to $\mathrm{I}$. Lower determination coefficient value $R^{2}$ (close to zero) means that the ability of free variables to simultaneously explain non-free variable variation is very limited. Determination coefficient value $R^{2}$ which is close to one means that free variables provides almost the whole information necessary to predict dependent variable variation.

Table 5

Determination Table $\left(R^{2}\right)$

Model Summaryb

\begin{tabular}{|l|l|l|lr|l|}
\hline $\begin{array}{l}\text { Mode } \\
1\end{array}$ & $R$ & $\begin{array}{l}R \\
\text { Square }\end{array}$ & $\begin{array}{l}\text { Adjusted } \\
\text { Square }\end{array}$ & $\begin{array}{l}\text { Std. Error of the } \\
\text { Estimate }\end{array}$ \\
\hline $\mathrm{I}$ & $.950^{\mathrm{a}}$ & .903 & .898 & $\mathrm{I} .03759$ \\
\hline
\end{tabular}

a. Predictors : (Constant), Role of Internal Audit, Role of Audit Committee

b. Dependent Variable: Implementation of Good Corporate Governance

Source: Output SPSS 22, 2017

According to table 5, the determination coefficient value $R^{2}$ is located in Adjusted R-Square column. The determination coefficient value is found $R^{2}=$ 0.898 , which means $89.8 \%$ of the dependent variable of implementation of good 
corporate governance is explained by the independent variable of role of audit committee and internal audit, and the remaining I0.2\% is explained by other than independent variable used in this research, like Sharia Supervisory Board (DPS) variable.

The following is an interpretation of hypothesis test results between independent variable, which is the role of audit committee and internal audit with its dependent variable, which is the implementation of good corporate governance: Influence of the Role of Audit Committee on the Implementation of Good Corporate Governance. The hypothesis test results above state that the role of audit committee variable positively and significantly influences the implementation of good corporate governance variable, as proven with significance level of 0.003 , which is lower than $0.05(0.003<0.05)$, while the value $t_{\text {count }}$ is 3.145 , which is higher than the value $t_{\text {table }}\left(t_{\text {count }} 3.145>2.02 \mathrm{I}\right)$. Therefore, as audit committee exists, all activities or all plans should be performed as the audit committee recommends. The higher the role of audit committee, the higher the application of good corporate governance in sharia banking is. On the contrary, the lower the role of audit committee, the less good the application of good corporate governance in sharia banking is. This results outcome is in line with the research of Dewi Megasari (2010), in which audit committee takes important role in the implementation of good corporate governance in sharia banking, which is advantageous in decision making and policy making in sharia banking.

\section{a. The Influence of the Role of Internal Audit on the Implementation of Good Corporate Governance}

The hypothesis test results above state that the role of internal audit variable positively and significantly influences the implementation of good corporate governance variable, as proven with significance level of $0.00 \mathrm{I}$, which is lower than $0.05(0.00 \mathrm{I}<0.05)$, while the value $t_{\text {count }}$ of 3.656 is higher than the value table of $2.02 \mathrm{I}$ ( $\mathrm{t}_{\text {count }}$ is $3.656>\mathrm{t}_{\text {table }} 2.02 \mathrm{I}$ ). Therefore, as internal audit exists, all activities or all plans should be performed as per internal audit's supervision. The stricter supervision is conducted by internal audit, the better the application of good corporate governance in sharia banking is. On the contrary, the less strict is the internal audit's supervision, the worse the application of good corporate governance in sharia banking is. This research outcome is supported by the research of Dewi Megasari (2010), in which supervision conducted by internal audit is very good for the application of good corporate governance in such sharia banking. According to the statement, the internal audit influences good corporate governance by supervise the procedures and systems run in sharia banking. 


\section{b. The Influence of the Role of Audit Committee and Internal Audit on the Implementation of Good Corporate Governance}

The hypothesis test results above state that the role of audit committee and internal audit variables simultaneously, positively and significantly the implementation of good corporate governance variable, as proven with significance level of $0.000<0.05$, with value $F_{\text {count }}$ of $185.946>F_{\text {table }} 3.23$. Therefore, as audit committee and internal audit exist, any decision on and supervision of activities or all plans should be performed as audit committee decides and internal audit supervises. Therefore, we may conclude that Audit Committee and Internal Audit may mutually and simultaneously affect the implementation of Good Corporate Governance. The determination coefficient value is $R^{2}=0.898$, which means $89.8 \%$ of dependent variable of the implementation of good corporate governance is explained by independent variable of the role of audit committee and internal audit, and the remaining I0.2\% is explained by other than the independent variable used in this research, like Sharia Supervisory Board (DPS) variable.

\section{E. CONCLUSION}

There is a role of Audit Committee to the implementation of Good Corporate Governance, which may be interpreted that Audit Committee positively and significantly influences Good Corporate Governance. The role of Internal Audit to the implementation of Good Corporate Governance shows a significant level. We may interpret that Internal Audit partially, positively and significantly influences Good Corporate Governance. Based on simultaneous hypothesis test, the value $\mathrm{F}_{\text {count }}$ is $\mathrm{I} 85.946$ and the value $\mathrm{F}_{\text {table }}$ is 3.23 ( $\mathrm{I} 85.946>3.23$ ) and the significance level is $0.000<0.05$, thus we may say that Audit Committee and Internal Audit mutually, positively and significantly influences Good Corporate Governance

\section{REFERENCES}

Al-Quran Karim

Adiwarman A. Karim. 20I0. Bank Islam Analisis Fiqih dan Keuangan. Jakarta: Raja Grafindo Persada.

Artanto, Dian. 2012. Interaksi Arduino dan labVIEW. Jakarta: Elex Media Komputindo. 
Devani P. P. 2014. Pengaruh Peran Komite Audit dan Dewan Pengawas Syariah Dalam Mewujudkan Good Corporate Governance untuk Meningkatkan Kinerja Bank Syariah. Bandung. Jurusan Akuntansi Fakultas Ekonomi Universitas Widyatama.

Dewi Megasari. 2010. Pengaruh Peran Komite Audit dan Dewan Pengawas Syariah dalam Mewujudkan Good Corporate Governance untuk Meningkatkan Kinerja Bank Syariah.. Jakarta : Jurusan Akuntansi Fakultas Ekonomi dan Bisnis Universitas Islam Negeri Syarif Hidayatullah.

Imam Ghozali. 20II. Aplikasi Analisis Multivariate dengan Program IBM SPSS 19. Semarang: Penerbit Universitas Diponegoro.

Rifda R. B. (2016). Pengaruh Peran Audit Internal, Komite Audit dan Dewan Direksi Terhadap Penerapan Good Corporate Governance. Makasar. Departemen Akuntansi Fakultas Ekonomi dan Bisnis Universitas Hasanuddin.

Sugiyono. 2012. Memahami Penelitian Kualitatif. Bandung: Alfabeta.

Wahyu N. Wiyono. 2010. Pengaruh Komite Audit dan Audit Internal dalam Mewujudkan Good Corporate Governance Untuk Meningkatkan Kinerja Bank Syariah. Jakarta: Jurusan Akuntansi Fakultas Ekonomi dan Bisnis Universitas Islam Negeri Syarif Hidayatullah.

Wibowo, 2009. Manajemen Kinerja. PT. Raja Grafindo Persada: Jakarta http://www.bi.go.id http://www.ojk.go.id 